\title{
日本列島と周辺海域の地震地体構造区分
}

\author{
垣見俊弘 \\ 財団法人 地農予知総合研究振興会* 松田 時彦・相 田 勇 \\ 東京工業大学大学院総合理工学研究科** 衣 笠 善 博
}

\section{A Seismotectonic Province Map in and around the Japanese Islands}

\author{
Toshihiro KaKIMI \\ 1-5-6 Kubogaoka, Moriya-shi, Ibaraki 302-0104, Japan \\ Tokihiko MATSUDA and Isamu AIDA \\ Association for the Development of Earthquake Prediction, 1-5-18 Sarugakucho, \\ Chiyoda-ku, Tokyo 101-0064, Japan \\ Yoshihiro KINUGasa \\ Interdisciplinary Graduate School of Science and Engineering, Tokyo Institute of \\ Technology, 4259 Nagatsuta, Midori-ku, Yokohama 226-8502, Japan
}

(Received April 5, 2002: Accepted November 22, 2002)

\begin{abstract}
A new seismotectonic province map of the Japanese Islands and the adjacent areas, which carries maximum magnitudes of earthquake $\left(\boldsymbol{M}_{\max }\right)$ expected for the individual provinces, has been prepared as a revised edition of Kakimi et al. (1994). The major part of the mapped region constitutes an island arc-trench system, which is surrounded by Northwest Pacific Basin (1), Shikoku Basin (2), Philippine Basin (3), Kurile Basin (4), Japan Sea Basins (5), and Korean Peninsula and Tonhai Continental Shelf (6). All of the peripheral provinces have too low seismicity to be given $M_{\max }$. The island arc-trench system is subdivided into the following constituent arcs: Kurile Arc (7), Northeast Honshu Arc (8), Izu-Bonin Arc (9), Southwest Honshu Arc (10), Ryukyu Arc (11), Sakhalin Arc (12), and the Tectonic Belt along the Eastern Margin of Japan Sea (13). While the constituent arcs 7 to 11 are divided into three tectonic belts, which remarkably differ from each other in tectonic, seismic, and volcanic activities, from the trench to the inland: Continental Slope on the Trench Side (A), Non-volcanic Outer Belt (B), and Volcanic Inner Belt (C), the constituent arc 10 alone has additionally the Continental Slope on the Marginal Sea Side (D). Province 12 started developing in Late Mesozoic and functioned as a collision belt between the North American Plate (NA) and the Eurasian Plate (EUR) in Late Cenozoic, whereas province 13 is considered to form a current collision belt between NA and EUR plates. Province $11 \mathrm{X}$, Okinawa Trough, is defined as a current rift zone developing between the Tonhai Continental Shelf and the Ryukyu Arc. Some of the provinces are further divided into subprovinces in response to local differences in active faults, seismicity, $M_{\max }$ etc.

All the active faults on land are grouped into seismogenic faults (Matsuda, 1990), which are considered to generate characteristic earthquakes. The magnitudes of earthquake expected for the seismogenic faults $(M L)$ are estimated by the equation: $\log L=0.6 M L-2.9$ (Matsuda, 1975), where $L$ is the length of the faults in kilometers. The maximum magnitude of earthquake expected for seismogenic faults $\left(M L_{\max }\right)$ and the maximum one for historical shallow earthquakes $\left(M h_{\max }\right)$ are compared in each province to choose the larger one as the expected maximum earthquake magnitude $\left(M_{\max }\right)$ for the province. Since no method to decide a seismogenic unit from offshore active faults has been established, $M h_{\max }$ is tentatively adopted as the $M_{\max }$ representing the province. Extraordinarily
\end{abstract}


long faults found in inland provinces, which are called the designated faults (Matsuda, 1990), are excluded from estimation of the $M_{\max }$. None of the magnitudes of earthquake expected for the designated faults is shown here, because they should be individually estimated. All of the information, such as tectonic geomorphology and geology, characteristics of active (seismogenic) faults, historical earthquakes, modern seismicity, and other, is put into a table to facilitate the identification of a seismotectonic province and the determination of the $M_{\max }$ and the designated faults. The details of the boundaries between seismotectonic provinces are shown in another table.

Key words: Seismotectonic province, Japanese islands, Arc-trench system, Maximum earthquake magnitude, Seismogenic fault.

§1.はじめに

日本列島と周辺域の地体構造を地覀活動に基づいて区 分し、それぞれに最大期待地原規模 $M_{\max }$ を示した区分 図としては, Omote et al. (1980) 以降, 松田 (1990), 萩 原編 (1991)，垣見・他 (1994)などが提唱されている. なお， $M_{\max }$ を指定してはいないか，地磭活動と活断局分 布の関係などを考悬した地体構造区分図としては，岡 田・安藤 (1979), 活断首研究会 $(1980,1991)$, 垣見 (1983), Kinugasa (1990), 松田・吉川(2001)などがあ る.

ここでは上記の各種区分図を比較した上で，垣見・他 (1994) の区分図を、各区の特徵, $M_{\max }$, 特定断層などに 関して，最新のデータと知見に基づいて改定し，新たな 地票地体構造区分図を作成することとした。

この区分図作成の主目的は，第一に日本列島の各地域 に予想すべき最大地震の規模を示すことであり，第二に は，その内部では地票活動（規模別発生頻度，発票機構 など）が共通とみなせる地域を、種々の地学的根拠に基 ついて区分することである.

\section{§2. 地震地体模造区分図の作成方䣄}

地票地体構造区分とは, 地票の起こり方の共通性, あ るいは差異に基づいて地体構造を区分することである [萩原編 (1991)]．したがって地票の起こり方のどの性質 に着目するかによって異なる区分があり得るが、ここで は主として地款内地票の規模の地域差を重視し、併せて 地票の頻度や発票機構とも調和のとれた区分となるよう に努めた。ここで扱う地縟の深さは，とくに断らない限 り, 内陸ではおよそ $20 \mathrm{~km}$ まで, 海域では $40 \mathrm{~km}$ 程度 までと考えてよい。これより深いところ一主としてサブ ダクション帯ーで起きる地票については, 別な区分図が 必要なことはいうまでもない。

本稿における地体構造区分の方針はおよそ以下のとお りである.

日本列島は島胍一海溝系に属しているから，まず，これ を取り囲む海洋底, 縁海盆, 大陸などを大地形に基づき 区分（1から6 まで）する. 本稿では，これらの区の地祳
活動は検討せず, したがって $M_{\max }$ も与えていない，

残る島弧一海溝系本体部を，7. 千島弧，8. 東北日本 弧，9. 伊豆小笠原弧，10. 西南日本弧，11. 琉球弧，12. 樺太弧，および13.日本海東縁変動帯に区分した。この うち樺太弧は，現在の島弧一海溝系とは斜交する古い弧 であるが，最近まで北米ーューラシアプレート間の街咨 境界であり，現在もその影䛲が認められることから，独 立して扱った。 また, 日本海東縁変動帯は, 最近新しく 北米ーユーラシアプレート間の収敛境界域として活動的 になった地帯であり，地縟の起こり方にす共通性がら れることから、独立の構造区として扱った．

各胍の内部では, 弧に平行して, 海䓓陸側大陸斜面に A, 島弧外帯 (非火山性外弧) に B, 島弧内帯 (火山性内 弧)にC, 緣海側大陸斜面にD D記号を与え, 区分した. これらの区分にあてはまらない琉球弧内の种縄トラフ や，樺太弧の区分には，W，X，Y，などの記号を与えた。 なお，典型的な島弧では，火山フロントを境に外帯之内 帯が区分されるのが一般であるが，西南日本砀では例外 的に，中央構造線を境に外帯と内帯を区分した，西南日 本弧は，典型的な島弧と比較するとその特徽が不明眿 で,火山帯ははるか内陸側（山陰地方）にあり、フロン トの位置もはっきりしない、いっぽう中央構造線はそれ 自体が活断首であるが，また活断層の多い内帯側と，き わめて少ない外帯側を分ける活断首フロント [Kinugasa (1990)] に位置しているから，島弧を活断層フロン トで内帯, 外帯に区分することにすれば，西南日本の地 震地体構造区分も例外的とはいえない.

最後に, 以上の区のなかで, 活断層の分布・断居夕イ プ・活動度や地覀の密度・発票機構などに顕著な差があ る場合, 大地票の発生域として区分できる場合，区内で 異なる $M_{\max }$ を与える必要がある場合などには，これを

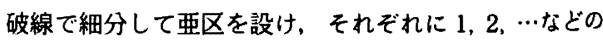
添字を与えた。

以上の区分を Fig. 1 に示す.

§3. 日本列岛と周辺海域の地体礶造区分 前節の方鈤に基づき，地農地体構造を下記のように大 


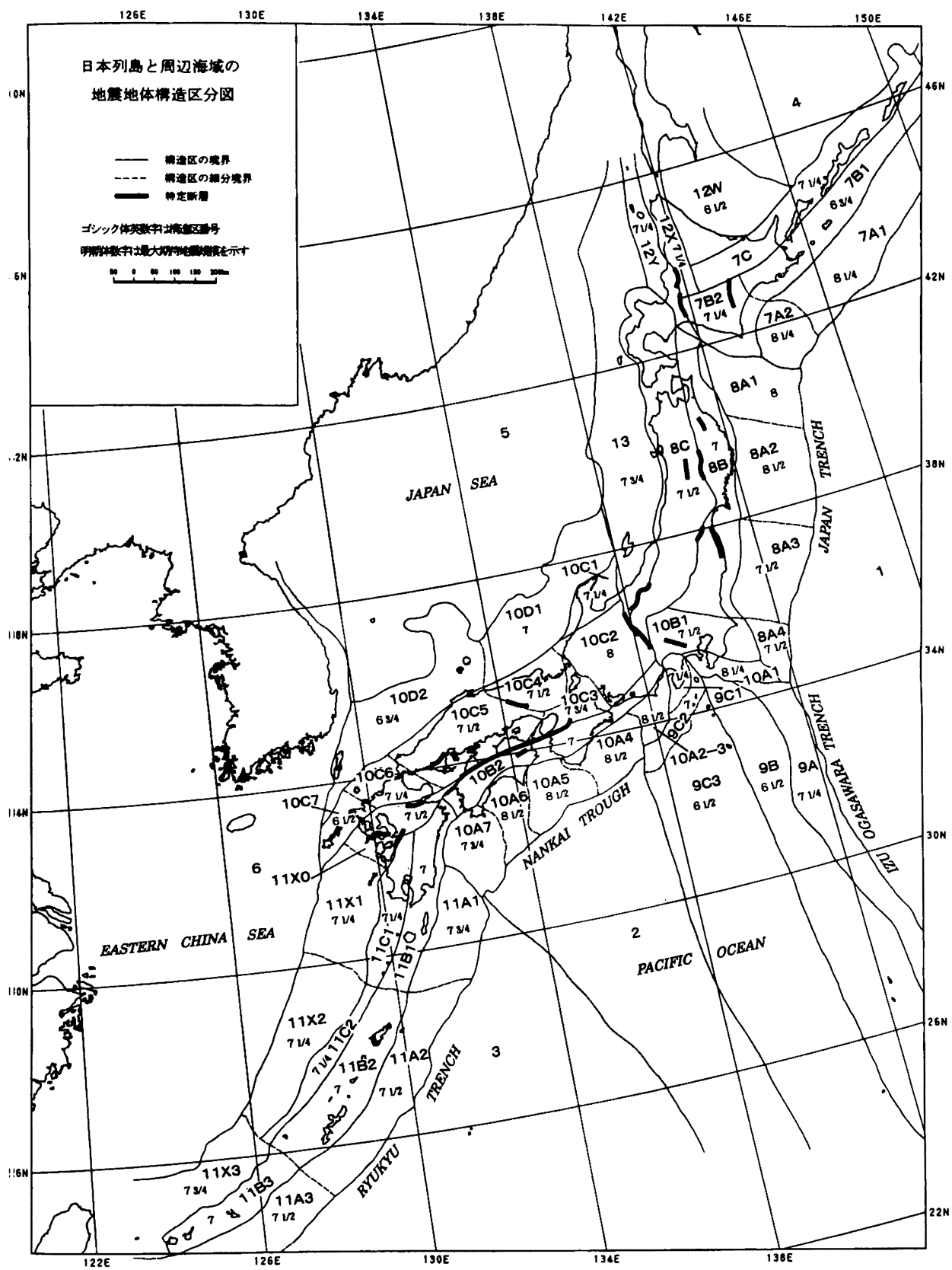

Fig. 1. Seismotectonic province map in and around the Japanese islands. Boldfaced sign is the symbol of province. Roman-type numeral represents the expected maximum earthquake magnitude $\left(M_{\max }\right)$ assigned to each province. Solid line: boundary between provinces. Broken line: boundary between subprovinces. Bar: the designated fault. 
区分した（Fig.1の実線区分）.

I. 日本列島周辺の大洋底と大陸域

1. 北西太平洋海盆

2. 四国海盆

3. フィリピン海盆

4. 千島海盆

5. 広義の日本海盆 (日本海盆・大和海盆・大和海 簿・対馬海盆とその周辺海域)

6. 朝鮮半島・東海大陸棚

II. 日本列島周辺の島弧陸域と島沉海域

7. 千島弧一(7A) 千島海溥大陸斜面, (7B) 千島弧外 帯, (7C) 千島弧内帯

8. 東北日本胍一 $(8 \mathrm{~A})$ 日本海溝大陸斜面, (8B) 東北 日本抔外帯, $(8 \mathrm{C})$ 東北日本弧内帯

9. 伊豆小笠原弧一 $(9 \mathrm{~A})$ 伊豆小笠原海䓓大陸斜面, (9 B) 伊豆小笠原弧外帯, (9C) 伊豆小笠原弧内帯

10. 西南日本础一 $(10 \mathrm{~A})$ 相模トラフ・南海トラフ大陸 斜面, (10B) 西南日本弧外帯, (10C) 西南日本弧内 帯、(10D) 日本海南縁大陸斜面

11. 琉球弧一(11 A) 琉球海溝大陸斜面, (11B)九州 • 琉球弧外帯, (11C) 九州・琉球弧内帯, (11X) 神縄 トラフ

12. 樺太弧一 $(12 \mathrm{~W})$ 日高・根室帯 (北部)，(12X) 石狩 天塩帯 (北部), (12Y) 礼文樺戸帯

13. 日本海東縁変動帯

上記の区分の大部分は，垣見・他 (1994) と同じであ るので,ここでは，区の新設を含め，垣見・他 (1994)の 区分を改変した区の, 改変理由, 内容, 境界などについ てのみ説明する。

(1)日本海東縁変動帯 (13) を新設

垣見・他 (1994) では島弧と縁海の境界域（大陸斜面） として扱ってきた日本海東縁部を, 新生プレート境界周 辺の変動帯として一括することにした，そのため，垣 見・他 (1994)のうち 8D 区（日本海東縁大陸斜面）と， 122 区（北海道西方大陸斜面）は削除した。

プレート境界の位置について, 中村 (1983) は, 日本海 盆一大和海盆の東縁の急斜面から, 富山深海長谷を経て 系魚川一静岡構造線にいたるところに置いたが, 近年, 大 竹 (1998) や石川 (1998) は, これより内陸側の, 1983 年 日本海中部地票-1964 年新潟地震の票源域から信洤川 沿いに“上陸”し1847 年善光寺地票の鋠源域を経て北 部フォッサマグナに至る線をブレート境界とした，後者 の場合だと，プレート境界の西側にも活断層の発達する 変動帯があることになる.ここでは，プレート境界の位 置にはこだわらず，活断首の分布する海域 [岡村 (1998) などによる）の西端を西側境界とし，この区を幅の広い
衙笑帯と位置づけた.なお，岡村・他 (1998) はこの区を 海底の構造地形などから 3 区分できるとしたか，今回は 区分せず，将来の課題としたい。

(2)干島弧外帯西端部 (7B2) の西側境界を西方へ移動 千島弧の外弧スリパー(7B) は西進して，中新世には 日高衝突帯を形成したことはよく知られているが, 現在 そのフロントは馬追衝上断届からその西側の勇払背斜 (苫小牧平野下) にまで及んでいるという[伊藤・他 (1999)]. この知見を参照し，7B2 の西側境界を，垣見・ 他 (1994) の神居古潭帯東縁線から, 札熀一苫小牧低地帯 東縁（馬追丘陵西縁）まで移動させ，石狩天塩帯 $(12 \mathrm{X})$ の南部を7B2にとり込んだ.

(3)千島弧内帯 $(7 C)$ に北限線を追加, その北側に日高 根室帯北部を新設

垣見・他 (1994)では，北海道の東北部からサハリン にかけてを、すへてて島弧内帯 (7C) としているが,これ は他の島弧系の区分から見ても不自然である。 そこで 7C を堆行火山列 (知床-阿寒-大雪) の北端付近以南に限 定し，かつ主部 (7C1) と西端部 (7C2) の区分線をとり 払って，千島弧内帯 $(7 \mathrm{C})$ に一括した，その北側は，樺太 胍の一部であることをあらわすために，日高・根室帯北 部 $(12 W)$ とした。

日高帯と根室帯は，もとは別々の構造区（マイクロプ レート）であり，中新世に合体したものである，その境 界は，北見大和堆西縁線一網走構造線 [垣見・他 (1994) で 7C1 と7C2 を区分した破線了といわれているか，現 在の地票活動に差異はみられないため,一括した。

(4)能登半島北部 $(10 \mathrm{C} 1)$ の南側境界を南へ移動

垣見・他 (1994) における $10 \mathrm{C} 1$ の南限を，中部山岳 (10C2)のなかで、綐ずれ断虽を主とする地域 (北部) と， 横ずれ断局を主とする地域 (中・南部) の境界の位置と した。また，その西方延長にあたる 10C4 区と 10D1 区 の境界線も微修正した。

(5)南海トラフ大陸斜面 (10A)のうち, 10A2 区と10A 3 区を合併

垣見・他 (1994) では，相模トラフ (10A1)を除く 10 $\mathrm{A}$ 区は東から駿河湾 (10A2)，遠州灌 (10A3)，以下日向 灌(10A7) までに6 区分され，それぞれ独立に，または 隣接区と連合して大地票を発生する区とされていた，し かし10A2 区ではこれまで単独で大地票を発生した記 録がなく，領域も他と比べて狭いこと，また地縟調查研 究推進本部地震調查委員会 $(2001 \mathrm{~b})$ [以下推本 $(2001 \mathrm{~b})$ という）毁河湾と遠州漠を 1 つの大地票発生域（領域 Z)としているので，ここでは，垣見・他 (1994)の10A

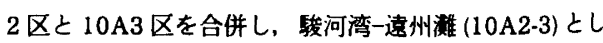
た. 
なお，推本 (2001b) は，坦見・他 (1994) の 10A5 区と 10A6区に相当する海域す併せて 1 つの地震発生区（領 域X）としているが，両区の境界の地形的特徵が明瞭な ので,ここでは垣見・他 (1994) の区分のままとし，今後 の課題としておく.

\section{\$4. 最大期待地䨗規模 $M_{\text {max }}$ について}

基本的な $\boldsymbol{M}_{\max }$ の決め方は，以下のとおりである。

(1) 各構造区の $M_{\max }$ は気象庁マグニチュードを $1 / 4$ 刻みで与える。

(2) 陸域を含む構造区では，区内の歴史地票の最大規 模 $M h_{\max }$ と，内陸の起縟断首（ただし，後述の特 定断層を除く)加予想される地磦の最大規模 $M L_{\text {max }}$ を比較し， $M_{\text {max }}$ を決める

（3）海域の構造区では，区内の $M h_{\max }$ 加 $M_{\max }$ を決 める.

(4) 区内の $M h_{\max }, M L_{\max }$ がいずれも 6.5 末満の区の $M_{\max }$ は $61 / 2$ とする。

$M_{\text {max }}$ を $1 / 4$ 刻みとしたのは，昔の地縟や活断層から 想定される地縟の $M$ 値は，0.1 刻みで表示するほどの精 度がないためである。 したがって，たとえば $M_{\max }$ が 7 $3 / 4$ とされた区の最大地磦は，M7.5よりは有意に大き く.8.0よりは明らかに小さいというほどの意であって, $M 7.75$ ということではない.しかし，個々の $M h$ や $M L$ は 0.1 刻みで示されることが多いので, 1/4 刻みとの対 応関係に誤解が生じないように，今回は以下のようなと り決めで $M_{\max }$ を与えた。

“ $M h_{\max }, M L_{\text {max }}$ が，それぞれN.1 N.3（Nはマグニ チュードの整数部), N.4 N.5, N.6〜N.8, N.9 N +1 の 範囲にある区の $M_{\text {max }}$ は，それぞれ $\mathrm{N} 1 / 4, \mathrm{~N} 1 / 2, \mathrm{~N} 3 / 4$, $N+1$ とする゙。具体的に示せば，たとえば $M h_{\max }$ か $M L_{\max }$ が 7.1 7.3 の範囲にある区の $M_{\text {max }}$ は $71 / 4$ と し, 7.4 7.5 である区の $M_{\max }$ は $71 / 2$ とする，といj ことである.

この取り決めによる 1/4 区間の境界は, 連続量として のMの系列に正確に対応させた $1 / 4$ 区間の境界より も，M值のやや低い側にシフトさせている。ここは $1 / 4$ 区間の中央值を $M_{\max }$ と考えたとき，それぞれが 0.1 刻 みの1区間を下回らないように（安全側に）取り決めた ためである。、いずれにしても， 0.1 刻みの $M$ 值を， $1 / 4$ 刻みの枠に等分にあてはめることはできない，したがっ $\tau, M_{\text {max }}$ を 0.1 の単位で予想する場合には, るとのデー 夕 $\left(M h_{\max }, M L_{\max }\right)$ にたちかえって考虑することが肝要 であろう。

\section{§ 5. 特定断展について}

\section{1 特定断原の定蓄・与え万}

ある構造区の起票断層のなかで，例外的に長い断層長 をもつものはこれを特定断層之呼び，その地票規模は別 途考虑することとして，本稿では示さず，またその区の $M_{\max }$ には採用しなかった。この方針は松田(1990) およ び垣見・他 (1994) と同じである。

特定断層の位置はFig. 1 にシンボル化して示し，その 名称と長さは, Table 1のコラム (6)に示した

ここでは, 松田・他 (2000) の起震断層長の表から, 特 定断層かどうかを判断した。この表は，活断層研究会 (1991)に示された，原則として確実度 I, II の活断層線 （群）が, 松田 (1990)による以下の基準を満たすものを, 一つの起票断首とみなし，その両端を結んだ直線距離で その長さを示したものである.

（1）周辺 $5 \mathrm{~km}$ 以内に他の活断層線のない孤立した $10 \mathrm{~km}$ 以上の断層.

(2) 相互の間隔が $5 \mathrm{~km}$ 以内であるほぼ同じ走向の断 層群

(3) 断首線の中点の位置が主断層線から $5 \mathrm{~km}$ 以上離 れている，走向を異にする断層

以下，これを“5 $\mathrm{km}$ 基準”と呼ぶことにする。

Table 1 に採用した特定断層の長さは，上記のように 松田・他 (2000) によったが，他の資料のなかで，地震評 価に大きな影響のあるもの一分割型か一括型かを判定し たもの，断層長が松田・他 (2000) の表と著しく異なる もの，など一は，その旨を表中に併記した，ただし，今 回は個々の断層に関する多くの論文・報告書のなかで, 以下の 3 種類のものに限り参照した.

(1)推本による地震規模の評価に関する公表資料 [平成 13 年末まで; 推本 $(1997,2001 \mathrm{a}, 2001 \mathrm{c}, 2001 \mathrm{~d})]$. (2)政府の交付金により地方自治体が行った調查の報告 で，専門家による委員会が評価に関与しているすの [平成 12 年度まで；福島県 $(1998,1999)$, 北海道 $(1998,2000)$, 兵庫県 (2001), 岩手県 (1998), 熊本 県 (1998), 宮城県 (2001), 大分県 (2001)].

(3) 200 万分の 1 活断首図編策ワーキンググループ (2000) [以下, WG (2000) と略] による 200 万分の 1 活断層図.

このうち(3)は, 今のところ 200 万分の 1 図しか公表 されていないか，断層長については，もとになった詳細 活断層 GIS データベース（2.5 万分の 1 スケール）から 直接測定した值 [幔元 (私信)] を示した.

特定断層のうち, 中央構造線活断層系之系魚川-静岡 構造線断層帯については，その評価が複雑なので，以下 にその要点を述べておく. 


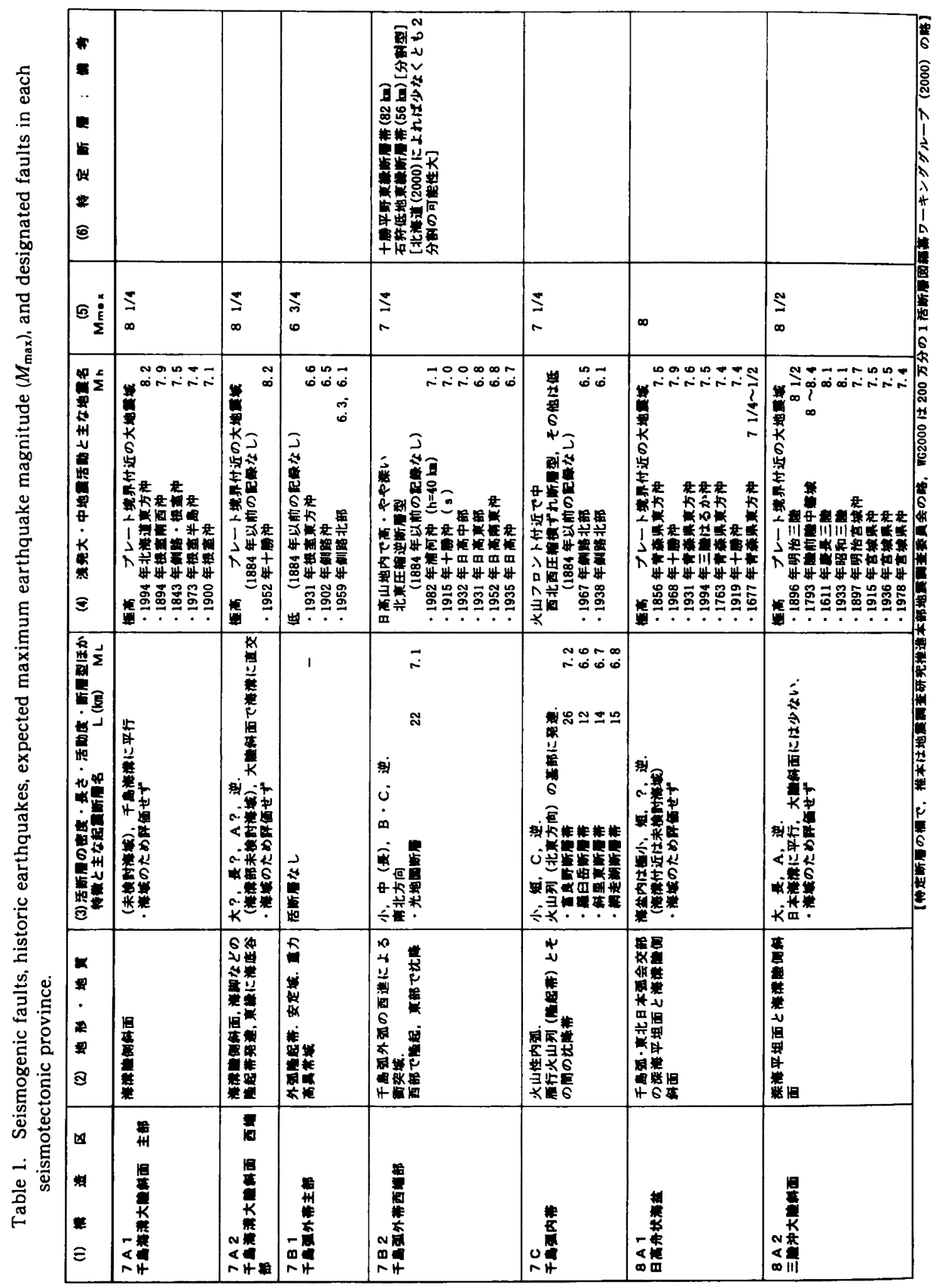




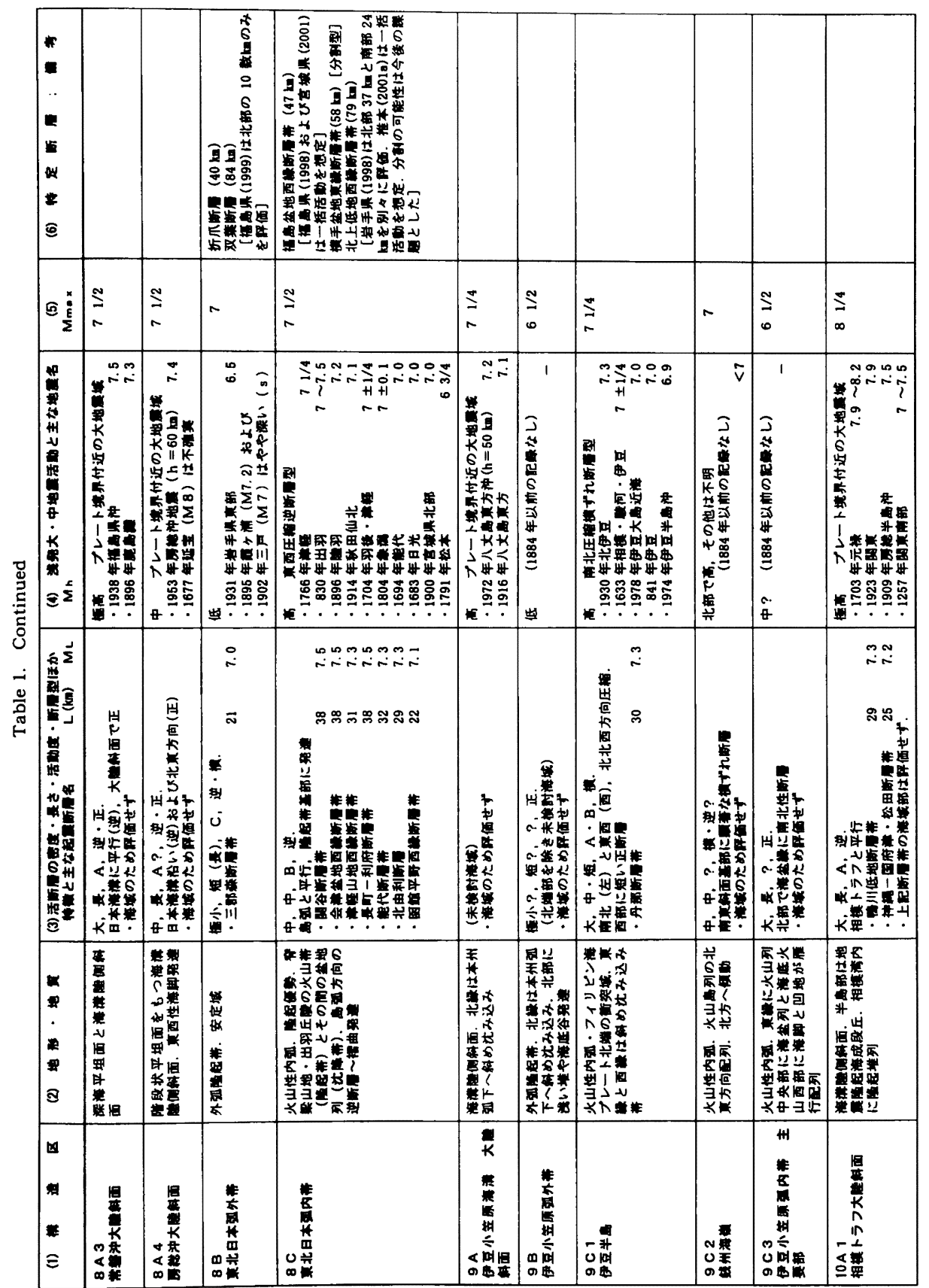




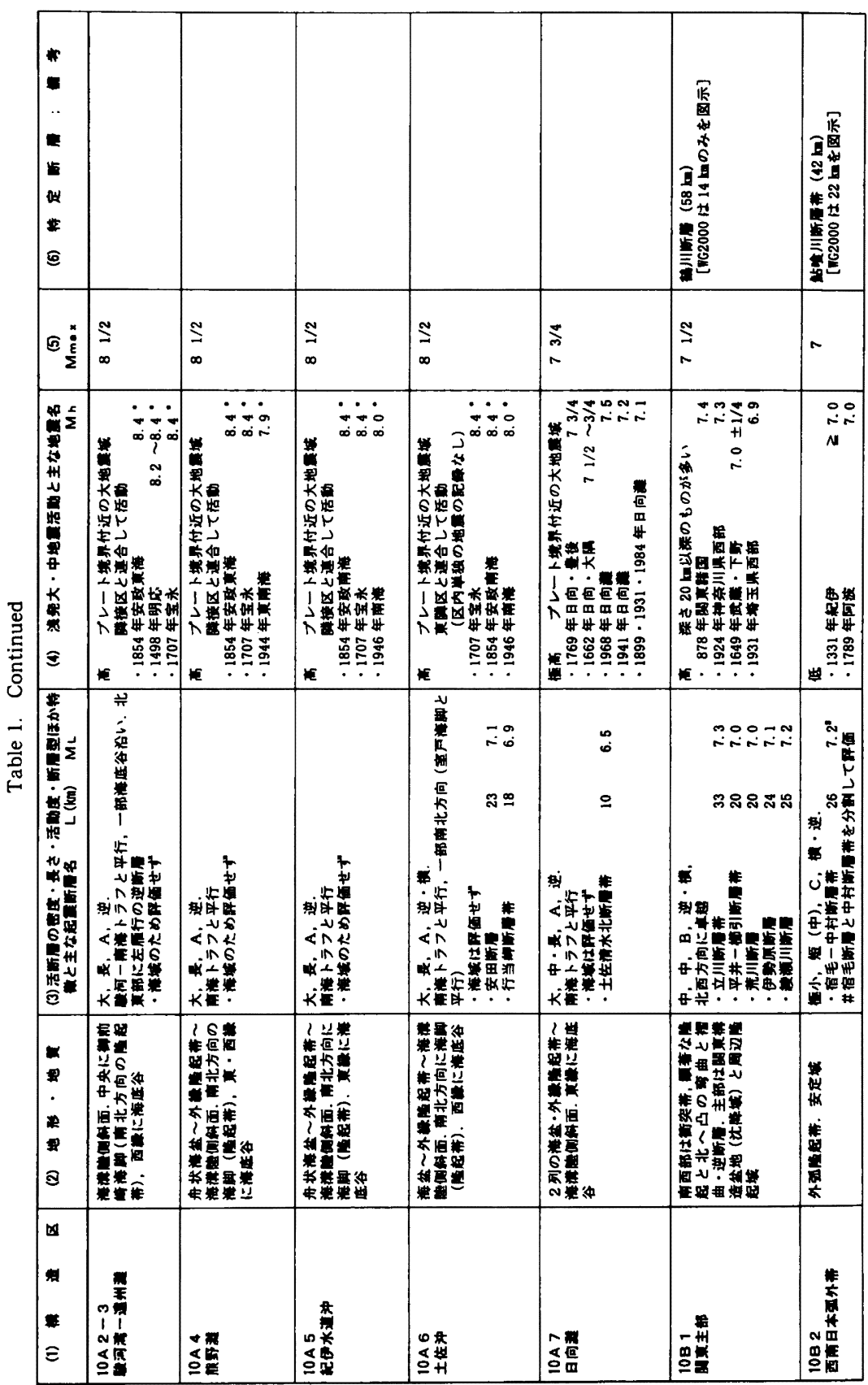




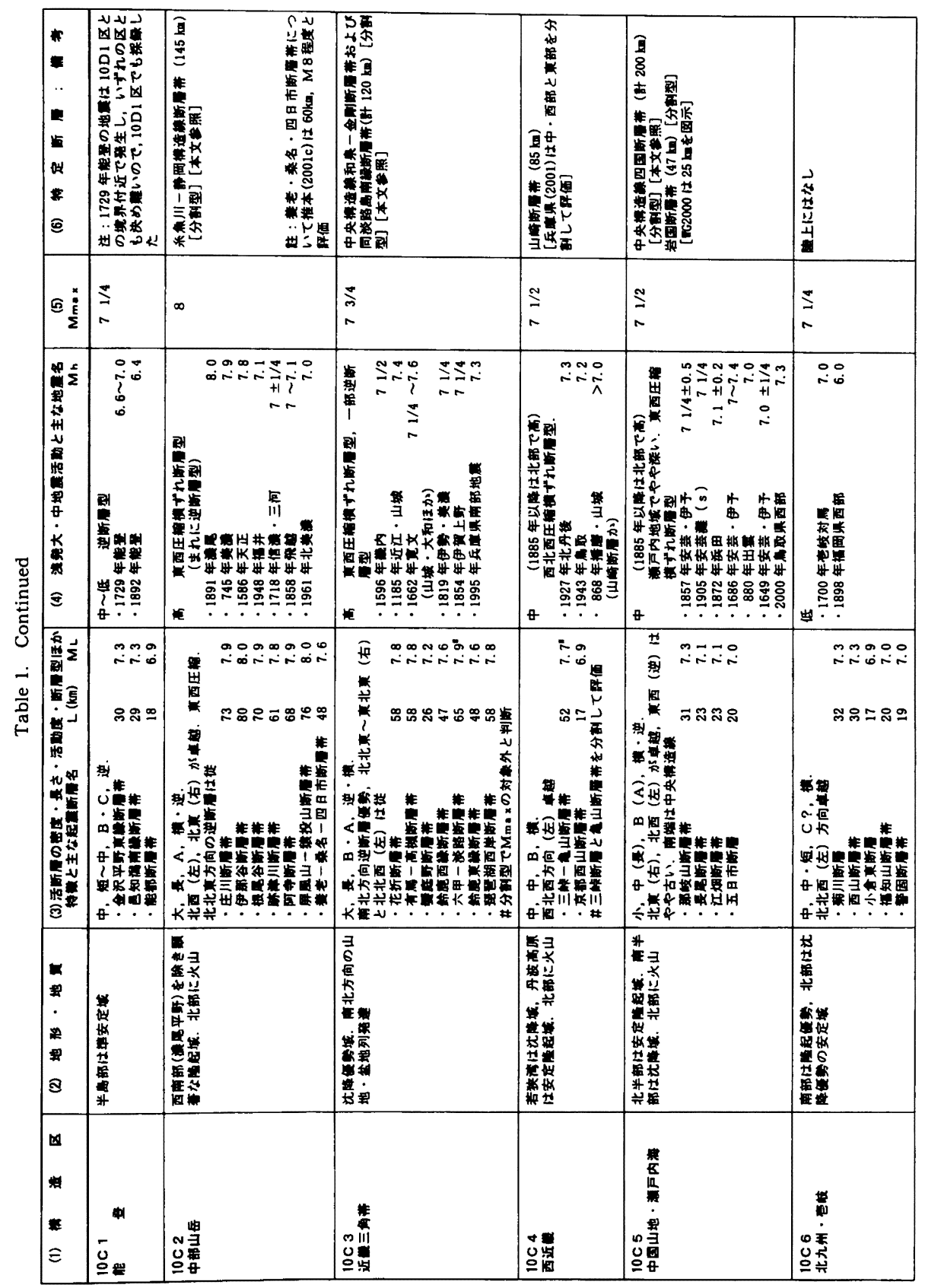




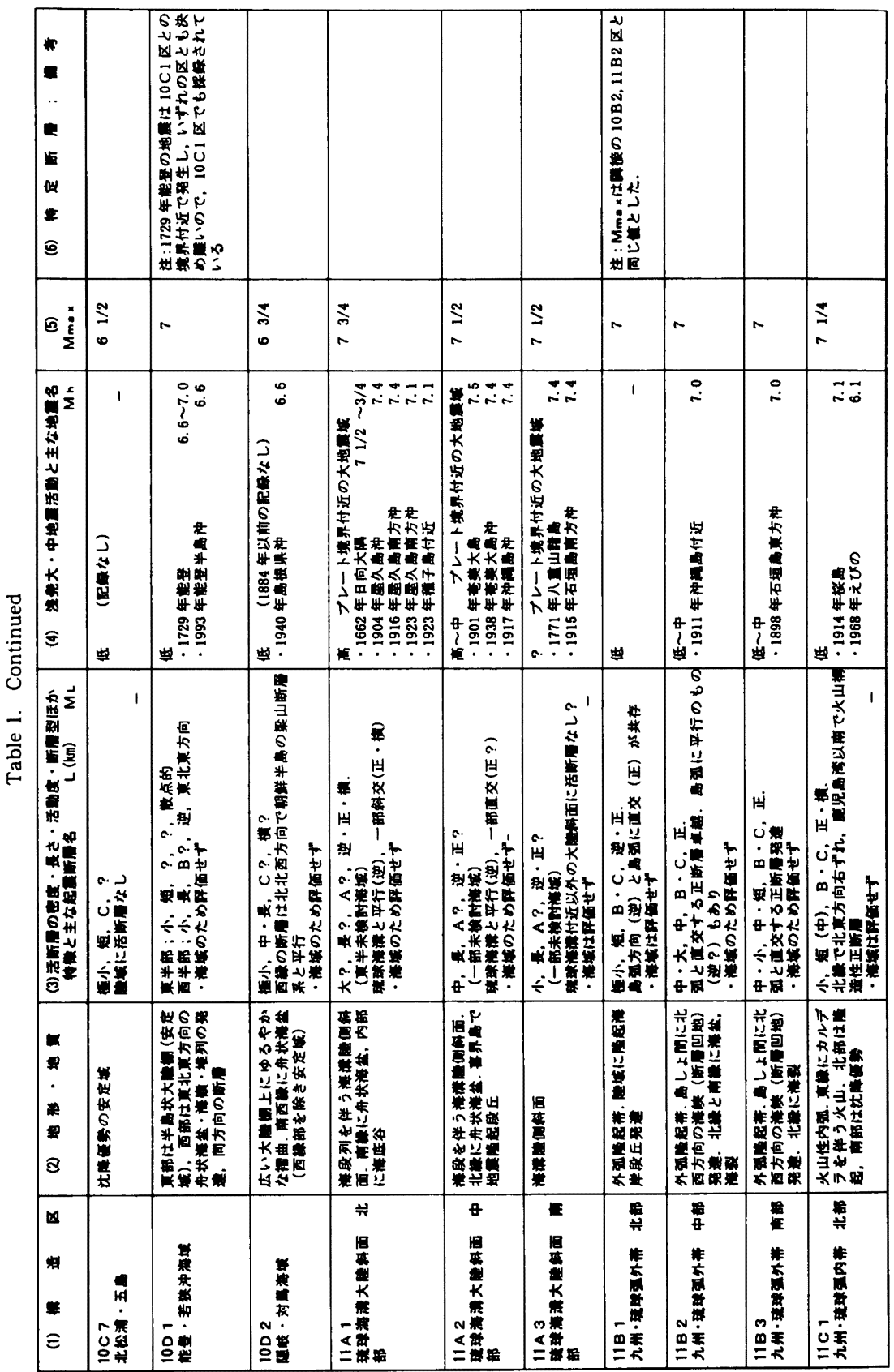




\begin{tabular}{|c|c|c|c|c|c|c|c|c|c|}
\hline 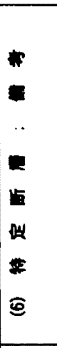 & 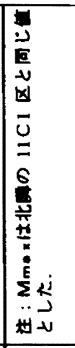 & 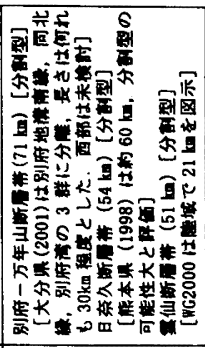 & 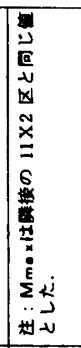 & & & & & 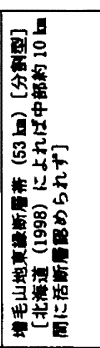 & 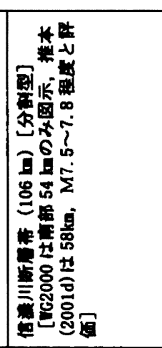 \\
\hline$\sigma \frac{\sigma}{\varepsilon}$ & $\Sigma$ & $\stackrel{N}{\sim}$ & $\Sigma$ & $\Xi$ & 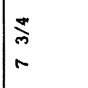 & $\underset{0}{\beth}$ & $\Xi$ & 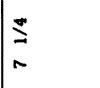 & ${ }_{\text {N }}^{*}$ \\
\hline 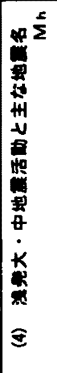 & 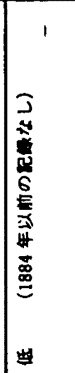 & 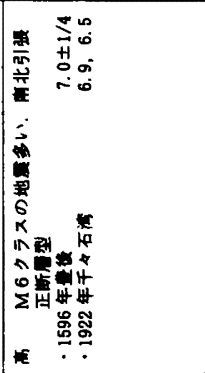 & 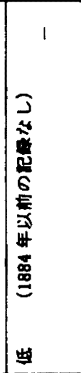 & 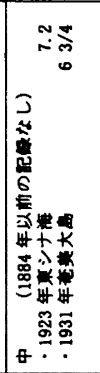 & 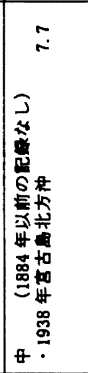 & 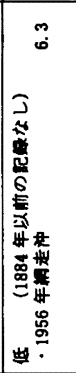 & 世 & 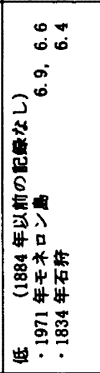 & 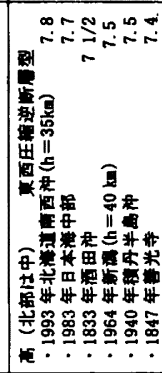 \\
\hline 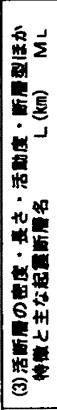 & 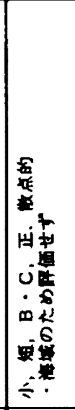 & 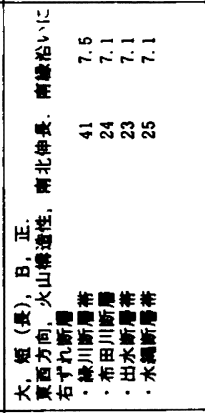 & 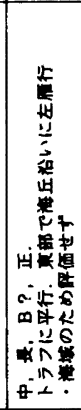 & 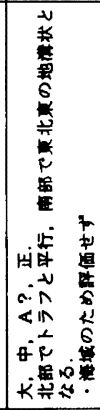 & 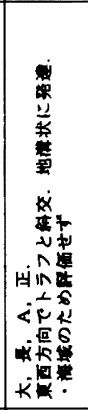 & 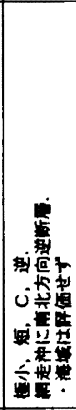 & 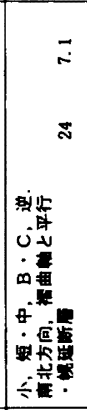 & 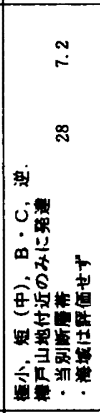 & 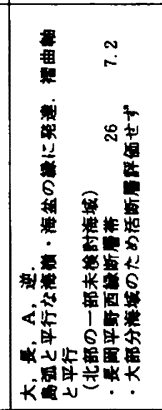 \\
\hline $\mid \begin{array}{l}2 \\
2 \\
0 \\
2 \\
3\end{array}$ & 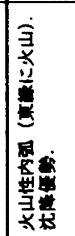 & 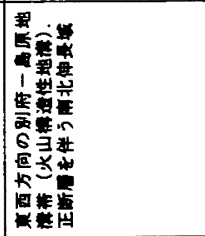 & 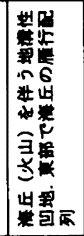 & 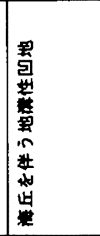 & 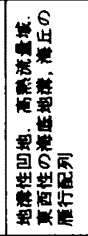 & 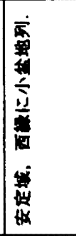 & 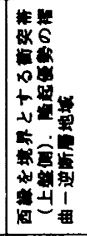 & 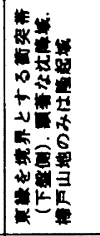 & 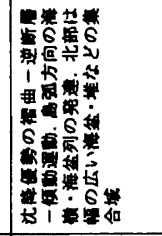 \\
\hline $\begin{array}{l}凶 \\
\cdots \\
\vdots\end{array}$ & 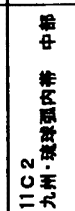 & 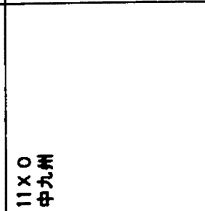 & 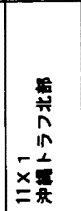 & 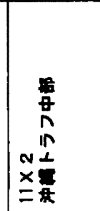 & 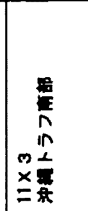 & 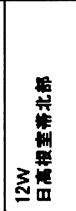 & 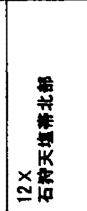 & 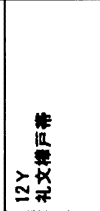 & 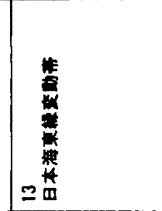 \\
\hline
\end{tabular}


400

\section{2 中央模造線活断间系}

松田・他 (2000) はこの活断層系を以下の起票断層帯 に区分している（以下，中央構造線を省略).

\begin{tabular}{|c|c|c|c|c|}
\hline a. 赤 & 石山 & 西縁断層帯 & $L 110 \mathrm{~km}$ & $M L 8.2$ \\
\hline b. 五 & 条-1 & 另断冨帯 & $98 \mathrm{~km}$ & 8.2 \\
\hline c. 四 & 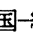 & 断首帯 & & \\
\hline$c-1$ & $"$ & 和泉-金剛区間 & $66 \mathrm{~km}$ & 7.9 \\
\hline$c-2$ & " & 紀伊水道区間 & $41 \mathrm{~km}$ & 7.5 \\
\hline$c-3$ & " & 讃岐山脈南縁区間 & $104 \mathrm{~km}$ & 8.2 \\
\hline$c-4$ & $"$ & 石鎚山脈北麓区間 & $48 \mathrm{~km}$, & 7.6 \\
\hline d. 川 & $I_{\mu}$ & & $17 \mathrm{~km}$, & 6.9 \\
\hline e. 伊 & & & $20 \mathrm{~km}$, & 7.0 \\
\hline
\end{tabular}

このうち $\mathrm{a}$ と bは, 活断層研究会 (1991) によれば大部 分は確実度 III であり，またWG (2000)によれば，a は 断片的な推定断層が示されているのみであり，bはまっ たく図示されていない，したがって，a,bの両断層帯は 特定断酋とする必要はないと判断し, Table 1 の(6)の 欄から外した。

一方，c-2, d および e の断首帯は，その長さからみる と特定断層とはならないか，しかし WG (2000) は海域 を除き，c-d-e をひと続きの断層帯として図示しており， 松田 (1990)の “5 km 基準”でも，上記のような起票断 層を設けることはできない.

中央構造線活断層系が分割型であることは, 最新活動 期の違いからみても確実であり，その起震区間について も幾つかの提案がある [岡田 (1992), 佃 (1996), Tsutsumi and Okada (1996), 中田・後藤 (1998), 後藤・他 (2000)など]. しかし現段階ではこれらの見解が一致し てはいないので, (6)の閵では仮に, 金剛〜淡路島南縁区 間 (計約 $120 \mathrm{~km}$ )を10C3 区の, 川上断層帯と伊予断層 帯を含む四国区間（計約 $200 \mathrm{~km}$ ）を 10C5 区の特定断 層とし，いずれあ分割型としておく.

\section{3 糸魚川一踭岡權造線断原带}

この断層帯 [松田・他 (2000) によれば全長 $145 \mathrm{~km}$ ] は, 東側隆起逆断首からなる北部区間 (約 $70 \mathrm{~km}$ ), 左ず れ成分の卓越する中部区間（約 $50 \mathrm{~km}$ ）および西側隆起 逆断首の南部区間（約 $30 \mathrm{~km}$ ）からなる. 南部は西側の 白州一節形山断層帯と，東側の下円井一市人瀬断層帯の 2 列に分かれる [下川・他(1995)]. 松田・他 (2000) は東 列を甲府盆地西縁断層帯 $(24 \mathrm{~km})$ として, 別な起票断層 としたが, 活動度からみると東列のほうを系魚川一静岡 構造線活断層帯の主断層帯としたほうがよいであろう [WG (2000)].

推本 (1997) は，約 1200 年前に北部・中部区間が同時 に活動した可能性［奥村・他(1996)などによる］を認 め,これと同じ地震であれば，将来 $M 81 / 4$ 程度までの
地震, さらに, 当時未検討であった南部区間を含めると M8 1/2 までの地震が発生する可能性があるとした. し かしその後の調査 [井上・他 (2000)など] により, 南部 区間の最新活動期は, 中・北部のそれとは有意に異なる ことが明らかにされた. 推本(1997) す, 各セグメントが 別々に活動する可能性は否定していない. そのため，将 来発生する地覀の規模は, $M 7$ 1/2 8 1/2 と幅広く想 定されているが，南部区間を含めなければ（中・北部と 同時に活動しなければ)，M7 1/2〜81/4 程度となろ う. いずれにしても，この断層帯のセグメンテーション の研究は現在進行中である. 本稿ではこの断層帯を $(145 \mathrm{~km})$ [分割型] としておく.

\section{\$ 6. 各檴造区の特徵と最大地震規模の表 (Table 1)}

Table 1 は，垣見・他 (1994) 以降の新しいデー夕・知 見も加え, 各構造区の特徽, $M_{\max }$, 特定断層, およびそ れらを決めるもとになった活断層・歴史地票デー夕をと りまとめたものである. 各コラムの記事内容は以下の通 り.

(1)「構造区」の橍：各区の記号と名称を示す.

(2)「地形・地質」の欄：区内の地形・地質・ネオテ クトニクスなどのうち, 特に隣接区と区別する理由とな るような顕著な特徵をキイワード的に示す．この欄の中 で, 安定, 隆起, 沈降, 褶曲, 断層, 火山などは, すへ て第四紀の活動をあらわす.

(3)「活断層の密度・長さ・活動度・断層型ほか特徴 と主な起票断首名」の欄: この闌の最上段にある大,

長, A, 横といった 4 文字は, 左から, 区内の主要な活断 層の分布密度, 長さ, 活動度, 断酋夕イプをそれぞれ略 示したものである. それぞれの区分は

(1)密度：大, 中, 小, 極小の 4 段階 [活断層研究会 (1991)の区分参照]

(2)主要断層の長さ: 長 (50 km 以上), 中 (20 50 $\mathrm{km})$, 短 (20 km 以下) の 3 段階

(3)主要断層の活動度 (平均変位速度): A, B , C の 3 段 階

(4)断首のタイプ: 正 (正断首), 逆 (逆断層), 横 (横 ずれ断層) の 3 種類. 横・逆などは, 区内における 横ずれ断層と逆断層の共存（前者が主）を示す（各 断層が横ずれ成分と逆断層成分を併せ持つ，という ことではない).

これらに続けて，区内の活断層の分布の偏り，方向性 などを示す, 以上の情報は, 主として活断層研究会 (1991)によるほか, 陸域ではWG (2000), 海域では海域 地質構造マップワーキンググループ (2001)のマップ （いずれも 200 万分の 1) をも参照した。（未検討海域） 
は，活断㖇研究会 (1991) が海域の活断届の存否を調査 した籍用外であることを示す。

この後には, 陸域にある主要起票断首の名称, 長さ $L$, 想定される地票規模 $M L$ を表示した. 二つの区の境界に ある断局は，便宜上分布密度あるいは $M_{\max }$ の大きい区 に所属させた。ここらは，とくに断らない限り，松田・ 他 (2000) の付表のデータをそのまま用いた. このデー 夕は，§5に詳述したように，活断層研究会 (1991) か図 示した原則として確実度 I と II の断首群を“5 km 基準” によってグループ化して $L$ を求め，松田 (1975) の経験 式により $L$ から $M L$ を想定したものである.

ごく少数だが, $M_{\text {max }}$ の判定に際して, 松田・他 (2000)のデー夕を採用しなかった断層すある.それは， (1)区内で最長（ただし特定断層には当たらない）とされ た断届で，かつ(2)その $M L$ が区内の $M_{\text {max }}$ に直接影㹕す ろものに限り，活断層研究会 (1991) やWG (2000) の図 に直接当たるなどして，個別に再検討した，その結果， 松田・他 (2000) と異なる評価をしたものは，\#印でその 旨を示した。

海域の活断層については $L, M$ の評価は行わず,「海域 のため評価せず」と記した，陸域の区でーとしたのは， $M L$ が 6.5 以上となる起莀断層が存在しないことを示 す.

（4）「浅発大・中地祳活動と主な地票名」の欄：この 排の最初に，すべての被害地票および 1885 年以降の $M$ 6 以上の浅い（陸域では深さ $20 \mathrm{~km}$ 以内および vs, 海 域では深さ $40 \mathrm{~km}$ 以内および vs, s) 地票の発生頻度を、 極高, 高, 中, 低の 4 段陼で示した。これ以外の，微小 地票データなどは，判断基準に入れなかった。

（記録なし）は当該区に上記の地縟の記録がないもの， （1884 年以前の記録なし）は，区内に 1884 年以前の上 記の地票の記録がないものを示した。

判明している限り, 各区の代表的な地縟の断層型（メ カニズム解）を示した. ただし、“ブレート境界付近の大 地震域 ${ }^{n}$ とある区の主要地震のメカニスムは，逆断首型 であるためすへて省略した。

主な地票としては，地区内に生じた地震のうち， $M_{\max }$ を決定する際に必要と思われる地震の発生年, 名称また は地区、マグニチュート $M h$ を示した．また地区内の最 大級の地震ではないが特街的な地縟として記載したもの もおる. デー夕は, 1884 年以前は宇佐美 (1996), 以後は 宇津 (1982) および気象庁資料による. 1884 年以前の地 票の票央に誤差範囲が示されているもの，およびマグニ チュードにさで幅が示されているものは，原則として中 央値を考虑した. 1885 年以降の陸域の地票については 特に断らない限り, 深さ $20 \mathrm{~km}$ を超える地票および深 さsの地祳は採用しなかった．また一は $M h 6.5$ 以上の 地票が記録されていないことを示す。

なお，南海卜ラフ大陸斜面の10A2-3〜10A6に付し た*は，その地区単独ではなく，隣接区と連合して起 こった地票の $M$ をあらわす。このうち 1707 年宝永地 磦の $M$ は，宇津 (1999) の表で 8.6 とされ, 推本 (2001b) もこれを引用している. しかしその根拠は示されていな いので,ここでは宇佐美 (1996) のデータのまま $M 8.4$ と した.

(5)「 $M_{\max } 」$ の橌: $M_{\max }$ の決め方，および垣見・他 (1994) と異なる点は，\$4 に示す通りである，ただし，琉 球弧に属する $11 \mathrm{~B} 1,11 \mathrm{C} 2,11 \mathrm{X} 1$ 区では $M 6.5$ 以上の地 票の記録が無いが，島弧方向の隣接区と比較すると海底 活断層の規模や性状がよく似ているため,これらの区の $M_{\text {max }}$ は隣接区と同じ值とし，(6)の欄にその旨を記し た。なお，南海トラフ治いの 10A2-3〜10A6の $M_{\max } 8$ $1 / 2$ は，その地区单独ではなく，隣接区と連合して起こ る場合の最大値を想定したものである，推本 (2001b) は，南海地票と東南海地震か同時発生した場合の $M$ は 8.5 前後となる可能性が高い, としている.

（6）「特定断層・備考」の欄：特定断層の定義および 具体的な与え方は 84 に示す通りである. 基本的には， 松田・他 (2000) の表により名称と長さが示されている ( $M L$ は不表示). そのあとに (分割型) と記したものは, 主として松田(1990)の Table 2 によっているか， その なかには最近の公的機関の調査で一括型を想定されてい るものもあり, 注意を要する。このほか, 限られた文献 （§5に示す）であるか，松田・他 (2000)の $L$ から予想 される $M L$ とは異なる規模評価がされた断層について は［］内にその旨を併記した。なお，系魚川-静岡構造 線と中央構造線の評価は，85 に別途示し，本欄では [本 文参照]としている.

\section{§7. 權造区境界一臨 (Table 2)について}

Fig. 1 の構造区分図は小縮尺なので，区の境界線の位 置の正確を期するために，個々の境界の位置を Table 2 に示した. Fig. 2 はその索引図である. Table 2 で欠番 となっているのは，垣見・他 (1994)で図示していた境 界を削除したところである。

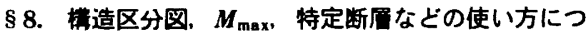 いて}

・ $M_{\max }$ となる地震の位置について: Omote et al. (1980)，松田 (1990) や垣見・他 (1994)のマップと同様 に，今回作成したマップでも，指定された $M_{\max }$ となる 地震の位置は，各構造区内の大規模な地票や起票断層の 


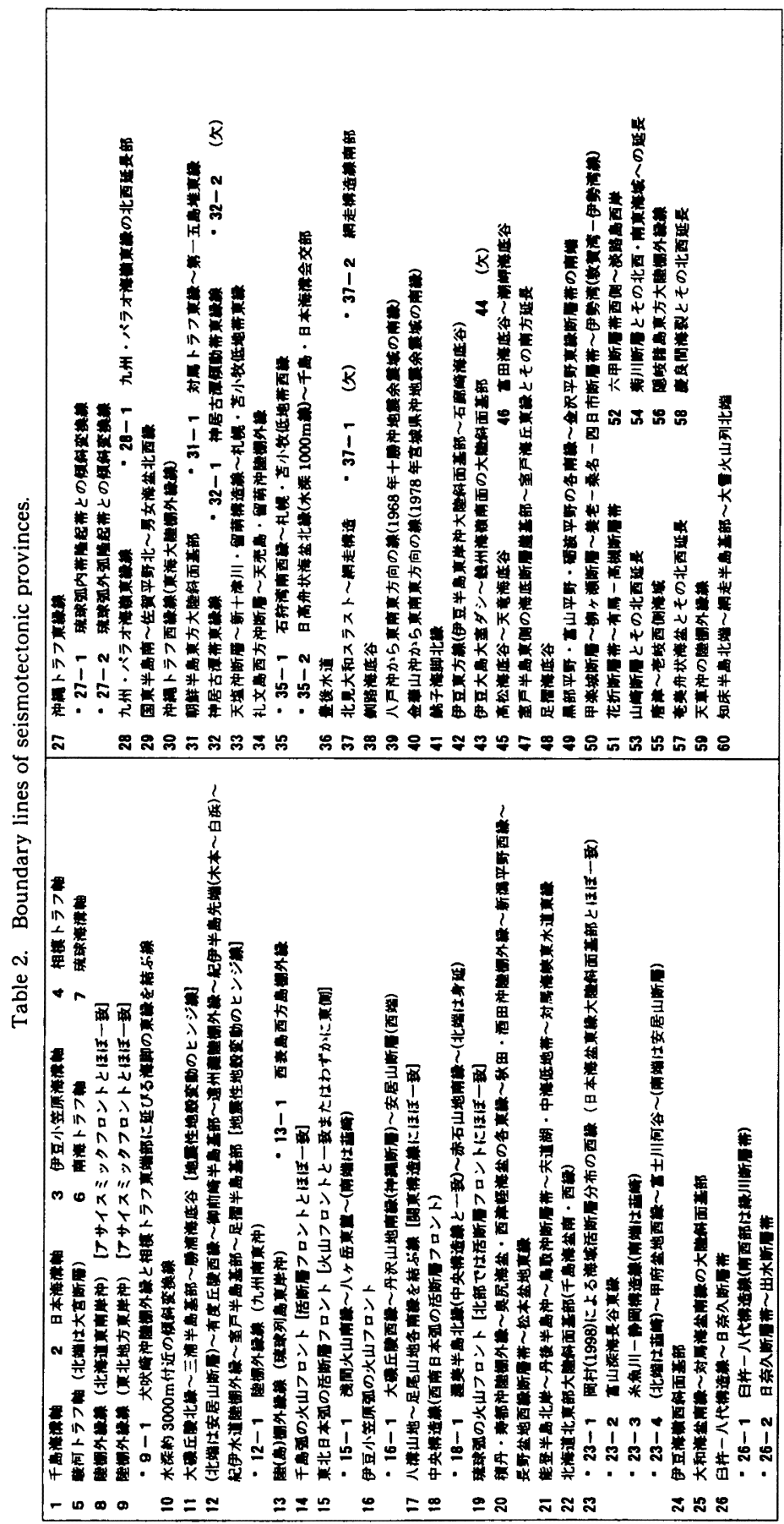




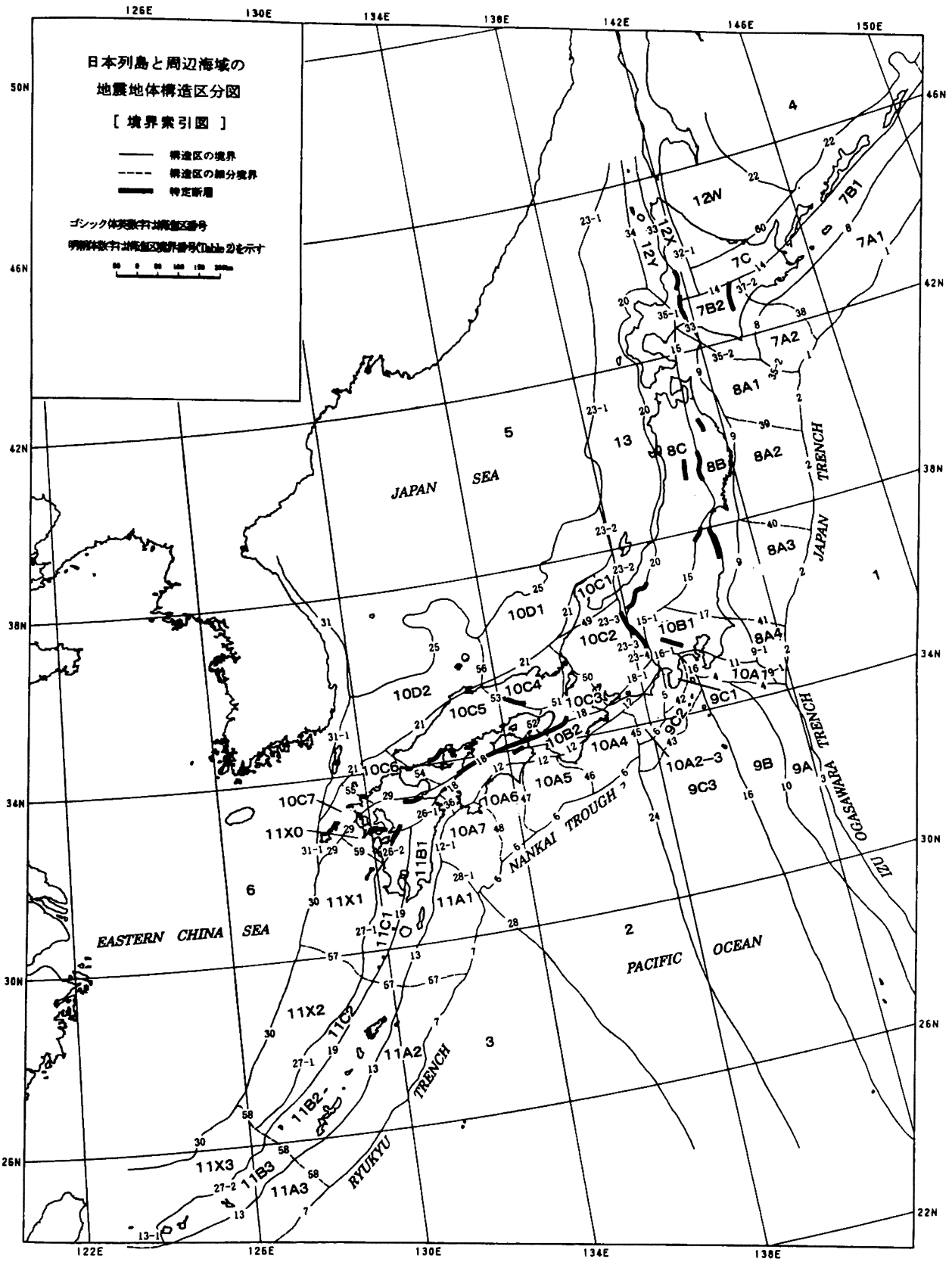

Fig. 2. Index map of boundaries among seismotectonic provinces. Numerals on boundary lines correspond to those in Table 2. Others are the same as shown in Fig. 1. 
位置を参照して決めることを想定しており，区内のどこ にでも起こり得ることを要求したものではない，ただ し，この想定は，区内の地震記録や起棖断届のデータが 十分整備されていることを前提としている. 文献だけで はそれらが不十分な地区での $M_{\max }$ の位置決定には，新 たな調查を加えるか，もしくは相当の自由度を与えて， その影雪を検討すべきであろう.（後段で述べる活断首 データの不確実性をも参照)

なお，本稿で $M_{\max } 61 / 2$ とした区の $M$ 值は，日本列 島の background 地㶾域に想定すべきいわば minimum requirement を示したものであるから，その地縟 は区内のどこにでも起こり得ると考えなければならな い.

・地票地体構造区分図の第二の役割：Fig. 1 には，隣 接する 2 区に同一の $M_{\max }$ をあたえている所がある. む し $M_{\max }$ を指定するためだけならば，2 区間の境界は不 要といえるが、ここでは $M_{\max }$ 以外の地体構造, 活断層 や地震活動に差があるために区別したものである。した がってこの区分図は，“票源を予め特定しにくい地襄” (推本ホームページ, 地震調查委員会, 平成 14 年 5 月 29 日による)の評価に際して, 地票の規模別発生頻度が 一様とみなせる地域を区分する基本図としても役立っと 考えられる.この場合には, 破線で示した要区の境界の 多くは取り払って, より広い範囲の地震を扱ったほうが よいかもしれない.

・活断層データの不確実性について：古い地票の震央 や $M h$ ，起展断層の $M L$ などのデータに大きな不確実性 があることはいうまでもない，本報告では，全国を同一 のレベルであらわす為に，古い地票については宇佐美 (1996)を, 起票断屏については活断酋研究会 (1991)に 基つく松田・他 (2000)をデータベースとした。このう 与起票断層は, 最近の調査により松田・他 $(2000)$ とは 異なった $M$ の評価がなされたものも少なくない，本報 告でも特定断層については、ごく限られた文献による が、異なる評価をされたものはこれを併記した。 しかし これ以外の起票断居は， $M_{\max }$ に影製する可能性のある 断層に限り再検討し，そのあるものは $M$ の評価を变え たものの, 他の大部分の断層は、全国同一レヘルの観点 から，松田・他 (2000) の表の $L, M L$ をそのまま表示し た.

例を挙げると, 垣見・他 (1994) で $M_{\max } 7$ とされた 10B2 区では，宿毛一中村断首帯 $(M L 7.2)$ は， $M$ が 7 を 超える唯一の起縟断局とされているが, 再検討の結果, この断層帯は活断屏でない可能性があり [WG (2000)], 活断首であっても分雕して評価できると判断し, 結局こ の区の $M_{\max }$ は 7 のままとした. 一方, $10 \mathrm{C} 1$ 区の $M_{\max }$
は垣見・他 (1994)では7とされているが, 境界の移動 により, 今回は邑知潟南縁断屏帯と金沢平野東緑断首帯 (ML はともに 7.3) が編入された. このうち前者は, 片 川・他 (2002)などの文献により，少なくとも分割型で あることが知られている. しかし後者は全区間が活動し た形跡がある [東郷・他(1998)] とされているため, 結 局, 金沢平野東縁断局帯の $M L$ によって，10C1 区の $M_{\max }$ は7 1/4 とされた.このため色知潟南縁断首帯 は，上記の観点から再検討の対象とならず，松田・他 (2000)の L, MLがそのまま表示されているが，このこ とは，同断首帯が分割型であることを否定したわけでは ない.

われわれは, Table 1 に表示した断局の $M L$ や地展の $M h$ は，区内の地票活動の大勢や，その限界の地震を見 極めるための参考値として示したものと考えている.し たがってューザーが個々の地震や断居について，詳細な 調查や信頼のできる文献によって,この表と異なる $M$ や $M_{\max }$ を採用することをさまたげるるのではない

また，本報告では，文献に示された海域の活断局は， 個別に評価していないが，それは起震区間や $M L$ を評価 するには精度不十分一なかには活断居に当たらないるの あある一のためであり，すべて無視してよいわけではな い. 文献で陸域の特定断局に相当するような長大な断層 が示されている場合には, それらによる地震発生の可能 生や，その規模にも考虑を払うべきであろう.

・票源の深さについて：この地票地体構造区分図は, 地形・地質学的観点から区分を行っているので，展源の 深さに対する配虎は，図の上に現れていない，しかしな から， 日本列島の島弧海湴系としての特徵によって区分 が行われたことから，構造区によってプレート境界地震 の発生領域と, 内陸地款内地票の発生領域とが明確であ る.

すなわち，構造区記号に A がつけられている構造区 (7A, 8A, 9A, 10A, 11A) は大陸斜面に属し, 大規模地震 は沈み込むプレート境界に発生する.したがって,これ らの構造区内に設定する辰源の深さは, プレート沈み込 み面の深さと考えることができる. プレート沈み込み面 の形状は、萩原編 (1991) などにも示されているが、こと に, フィリピン海プレートの形状に関しては議論も多い ので, 最新の知見で対処することが望ましい.

その他の構造区（B：島弧外帯, C: 島弧内帯,など) は, 地款内の地長が検討の対象になる. 地款内地震の発 生する深さについては, Ito (1999)などで検討されてい るが、ここに示した構造区分よりさらに高い地域性を もっている. したがって, 対象地祳ごとにその震源域周 辺の地票発生届の深さを参照する必要があろう. 
なお，日本海東縁（13区)、沖縄トラフ (11X)につい ては, 地震の深さに関して別途検討を要する。

また，スラブ内地震についても，別途検討が必要であ ろう.

\section{辞}

本稿は, 財団法人 地票予知総合研究振興会内に設け られた、サイスモテクトニクス研究会, 地票地体構造 マッフ十委員会 [萩原幸男 (委員長), 伊藤 潔, 岡田義光, 垣見俊弘, 衣笠善博, 隈元 崇, 谷 威, 佐藤比呂志, 武村雅之、堀内茂木，松田時彦、各委員]のご討議を経 てまとめられたものである．熱心なご検討と，貴重なご 意見を頂いた各位に対して，厚く感謝の意を表する.

また，担当編集委員および査読者池田安隆氏，匿名氏 には本稿を改善するに当たって貴重なご意見を頂いた。 記して厚く感謝の意を表する.

\section{文嗝}

福島県, 1998、福島盆地西縁断首帯に関する調䍒, 第 2 回活断層調查成果報告会予稿集，科学技術庁，69-72.

福島県, 1999, 双葉断層に関する調查, 第 3 回活断層調 查成果報告会予稿集, 科学技術庁, 49-58.

後藤秀昭・中田 高・高田圭太, 2000 , 詳細活断層分布 からみた中央構造線活断層系の連続性, 月刊地球，号 外 28, 73-79.

萩原尊禮編, 1991, 日本列島の地震, 地磭工学と地票地 体構造, 鹿岛出版会, $215 \mathrm{pp}$.

北海道, 1998, 増毛山地東縁断屋帯に関する調查，第 2 回活断層調查成果報告会予稿集, 科学技術庁, 33-40.

北海道，2000，石狩低地東縁断廈帯に関する調査，第 4 回活断層調査成果報告会予稿集，科学技術庁，19-28.

兵庫県, 2001 , 山崎断層帯に関する調查, 2001 年活断 首調査成果および推積平野地下構造調查成果報告会予 稿集, 文部科学省, 別刷 1-8.

井上大策・宮脇勝義・遠田晋次 -三浦大助・阿部信太 郎・上田圭一・青柳恭平 - 憣谷竜太, 2000 , 糸魚川静岡構造線活断層系の活動性解明に向けて一南部セグ メントの活動性について一月刊地球，号外 28，101112.

石川有三, 1998, 日本海の変動帯, 月刊地球, 20,490496.

Ito, K., 1999, Seismogenic layer, reflective lower crust, surface heat flow and large inland earthquakes, Tectonophysics, 306, 423-433.

伊藤谷生・森谷武男・井川秀雄・井川 崇・在田一則 津村紀子・篠原雅尚・宮内崇裕・木村 学・奥池司 郎・清水信行・井川 猛, 1999, 日高衝突帯における デラミネーションーウエッジ構造, 月刊地球, 21, 130-136.

岩手県, 1998 , 北上低地西縁断居帯に関する調査, 第 2 回活断屏調查成果報告会予稿集, 科学技術庁, 59-68. 地票調査研究推進本部地縟調査委員会 (推本), 1997 ,
糸魚川-静岡蔧造線活断首系の調查結果と評価につい て, 地㖘調查委員会報告集一 1995 年 7 月 1996 年 12 月, 501-510.

地震調查研究推進本部地票調査委員会 (推本), $2001 \mathrm{a}$, 北上低地西縁断瀜帯の評価，サイスモ，5-7，10-11。 地票調查研究推進本部地縟調查委員会 (推本), $2001 \mathrm{~b}$, 南海トラフの地覀の長期評価について, サイスモ，511, 7-12.

地票調査研究推進本部地震調查委員会 (推本), 2001c, 暴老-桑名一四日市断㾍帯の評価, サイスモ，5-12,89.

地震調查研究推進本部地震調查委員会 (推本), 2001d, 信濃川断層帯 (長野盆地西縁断層帯) の評価, サイス モ, 5-12,10-11.

海域地質構造マップワーキンググループ，2001，日本周 辺海域の第四紀地質構造図，海洋調查技術，13-1，付 図.

垣見俊弘，1983，日本内陸の活断層之被害地票の地域的 相関，地質調查所月報，34，295-309.

垣見俊弘・岡田篤正・衣笠善博・松田時彦・米倉伸之, 1994, 日本列島の地票地体構造区分之最大地縟規模, 地球惑尾科学関連学会 1994 年合同大会予稿集, 302 .

片川秀基・北目啓・伊藤 孝・穴田文浩・吉田 進 • 藤井昌彦, 2002, 石動・宝達山地北西部の地塊区分之 活構造, 地学雑誌, 111, 16-32.

活断酋研究会編，1980，日本の活断層一分布図と資料， 東京大学出版会, $363 \mathrm{pp}$.

活断層研究会編，1991，新編日本の活断層一分布図と資 料, 東京大学出版会, $437 \mathrm{pp}$.

Kinugasa, Y., 1990, Seismotectonic zonation based on the characteristics of active faults in Japan, USGS Open-File Rept., 90-98, 15-17.

熊本県, 1998, 日奈久断層に関する調査, 第 2 回活断層 調查成果報告会予稿集，科学技術庁，175-184.

松田時彦，1975, 活断首から発生する地票の規模之周期 について, 地票 $2,28,269-283$.

松田時彦, 1990, 最大地票規模による日本列島の地票分 帯図, 地票研究所重報, 65, 289-319.

松田時彦・塚畸明美・萩谷まり，2000，日本陸域の主な 起票断層と地票の表一断層と地票の地方別分布関係。 活断層研究, 19,33-54.

松田時彦・吉川真季, 2001 ，陸域の $M \geqq 5$ 地震と活断層 の分布関係一断層と地票の分布関係その 2 , 活断首研 究, 20, 1-22.

宮城県, 2001, 福島盆地西縁断層帯に関する調查, 2001 年活断層調查成果および堆積平野地下構造調查成果報 告会予稿集, 文部科学省, 147-156.

中村一明, 1983, 日本海東縁新生海溝の可能性, 地票研 究所策報，58，711-722.

中田 高・後藤秀昭, 1998, 活断層はどこまで割れるの か? 一横ずれ断首の分岐形態と縦ずれ分布に着目し たセグメント区分モデルー，活断層研究， 17，43-53.

200 万分の 1 活断層図編具ワーキンググループ (WG), 2000,200 万分の 1 日本列島活断層図, 活断層研究, 19 , 添付地図.

岡田篤正, 1992, 中央構造線活断層系の活動区の分割試 案, 地質学論集, 40, 15-30. 
岡田篤正・安藤雅孝，1979，日本の活断層と地䟴，科 学, 49, 158-169.

岡村行信, 1998, 日本海東縁海域の逆断層之地款短縮量 推定の試み, 月刊地球，20，460-465.

岡村行信・倉本真一・佐藤幹夫, 1998 , 日本海東縁海域 の活構造及びその地票との関係，地調月報，49，1-18.

奥村晃史 - 井村隆介- 今泉俊文・澤 祥 - 東郷正美, 1996、系魚川一静岡構造線活断層系の活動履歴調查、 地質調查所研究資料集， 259, 89-94.

Omote, S., Y. Ohsaki, T. Kakimi and T. Matsuda, 1980, Japanese practice for estimating the expected maximum earthquake force at a nuclear power plant site, Bull. New Zealand Nat. Soc. Earthq. Eng., 12, 37-48.

大分県, 2001 , 別府一万年山断娓帯に関する調查, 2001 年活断層調查成果及び堆積平野地下構造調查成果報告 会予稿集, 文部科学省、205-214.

大竹政和, 1998, 日本海東縁部の地震発生ポテンシア ル, 月刊地球, $20,449-454$.

下川浩一・水野清秀・井村隆介・奥村晃史・杉山雄一 ・

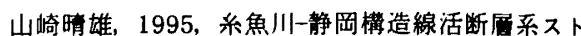
リップマップ, 構造図 11 , 地質調査所.

東郷正美・池田安隆・今泉俊文・澤 祥 - 平野信一, 1998, 森本一富樫断層帯の詳細位置と活動性につい $\tau$, 活断㢄研究, 17, 72-83.

佃 栄吉, 1996, 中央構造線活断層系のセグメンテー ションと周刃の地質構造, テクトニクスと変成作用 (螅本利彦・他編), 創文, 250-257.

Tsutsumi, H. and A. Okada, 1996, Segmentation and Holocene surface faulting on the Median Tectonic Line, southwest Japan. J. Geophys. Res., 101, 58555871.

宇佐美龍夫, 1996, 新編日本被害地票総覧, 増補改訂 版, 416-1995, 東京大学出版会, $495 \mathrm{pp}$.

宇津徳治, 1982 , 日本付近の $M 6.0$ 以上の地展および被 害地㖘の表：1885 1980 年, 地票研究所荣報, $\mathbf{5 7}$, 401-463.

宇津徳治, 1999, 地震活動総説, 東京大学出版会, 876 pp. 